\author{
Michala Benešová (iD https://orcid.org/0000-0002-1376-7978 \\ Uniwersytet Karola, Praga \\ michala.benesova@ff.cuni.cz
}

\title{
Kilka uwag na temat czeskiej recepcji polskiej tradycji reportażowej
}

\begin{abstract}
A Few Remarks on the Topic of Czech Reception of the Polish Reportage Tradition
Abstract: The article reflects on the chosen aspects of the Czech reception of the so called Polish school of reportage. Using a few specific examples, it analyses which Polish reportage texts appear in Czech translation, how are they received and which picture of Polish reportage emerges from such reflection. For analysis purposes chosen were first and foremost these texts, which in some way present the genre characteristics of the Polish reportage or the cultural differences in its reception by Polish and Czech readers.
\end{abstract}

Keywords: reportage, Polish literature, Czech Republic, Mariusz Szczygieł, Wojciech Tochman, Paweł Smoleński

Streszczenie: Artykuł podejmuje refleksję nad wybranymi aspektami czeskiej recepcji tak zwanej polskiej szkoły reportażu. Na kilku konkretnych przykładach analizuje, jakie polskie teksty reportażowe ukazują się w czeskich przekładach, jak są one odbierane i jaki obraz polskiego reportażu wyłania się z takiej refleksji. Do analizy wybrane zostały przede wszystkim te materiały, które w jakiś sposób uwzględniają specyfikę gatunkową polskiego reportażu lub kulturowe różnice w odbiorze polskich tekstów reportażowych przez polskich i czeskich czytelników.

Słowa kluczowe: reportaż, polska literatura, Czechy, Mariusz Szczygieł, Wojciech Tochman, Paweł Smoleński

Aby odpowiedzieć na pytanie, jak tak zwana polska szkoła reportażu postrzegana jest w czeskim środowisku, należy zastanowić się nad dwiema kwestiami. Po pierwsze: jak zdefiniować tak zwaną polską szkołę reportażu? Czy to pojęcie jest do utrzymania? Czy nie jest zbyt szerokie? I co oznacza w nim przymiotnik „polska”, to znaczy, co odróżnia polską szkołę reportażu od tradycji reportażowych innych krajów? Po drugie: czy w środowisku czeskim jest miejsce na bardziej kompleksową refleksję nad tym zjawiskiem? Czy Czesi w ogóle postrzegają go jako coś spójnego, czy mają świadomość specyfiki gatunkowej reportażu? 
W tym krótkim tekście nie ma wystarczająco dużo miejsca, aby gruntownie odpowiedzieć na pierwsze pytanie, postaram się więc jak najkrócej zarysować punkt wyjścia. Podobnie jak Magdalena Piechota uważam, że określenie „polska szkoła reportażu” ma raczej charakter kulturowy, „wskazuje bowiem na specyfikę warunków historyczno-społecznych, w jakich owa szkoła się wykształciła, a raczej w jakich wybitni twórcy-indywidualiści, każdy po swojemu, szukali sposobów na opowieść o współczesności”'. Charakter kulturowy będzie ono miało również w odniesieniu do czeskiej recepcji, ponieważ czeski czytelnik z zasady akcentuje nie tylko aspekt geneologiczny tego terminu, ale często także atrybut "polska” (do większego zainteresowania czeskich czytelników gatunkiem reportażu z pewnością przyczyniły się właśnie przekłady polskich tekstów).

Przyjrzyjmy się zatem bardziej szczegółowo temu, jakie polskie teksty reportażowe ukazują się w czeskich przekładach, jak są one odbierane i jaki obraz polskiego reportażu powstaje na podstawie tej refleksji. Ze względów czysto pragmatycznych, głównie z racji długości niniejszego tekstu, artykuł ma raczej charakter wstępnych refleksji oraz przybliża temat na kilku wybranych przykładach, gdyż samo zagadnienie jest znacznie szersze. Materiałem źródłowym będą przede wszystkim teksty krytyków literackich i innych recenzentów publikowane w czasopismach lub w internecie. W szczególności, z powodów, które przedstawię w kolejnych akapitach, skupiam się na tekstach opublikowanych po 2007 roku albo w czeskich gazetach codziennych i tygodnikach (ewentualnie miesięcznikach literackich), albo - w mniejszym stopniu - na stronach internetowych lub blogach literackich. Krytyczna refleksja nad polskim reportażem jest w Czechach wciąż zagadnieniem mniejszościowym (w porównaniu na przykład z publikowanymi recenzjami prozy zagranicznej). W związku z tym większość z nich to raczej pojedyncze recenzje danej publikacji. Spośród nich wybieram do analizy przede wszystkim te, które w jakiś sposób uwzględniają specyfikę gatunkową polskiego reportażu lub kulturowe różnice w odbiorze polskich tekstów reportażowych przez polskich i czeskich czytelników.

\section{Przed Gottlandem i po nim}

W czeskiej recepcji polskiej szkoły reportażu kluczowe jest nazwisko Mariusza Szczygła. Największym zainteresowaniem cieszył się jego Gottland, który w 2007 roku odniósł bezprecedensowy sukces także w Czechach². Choć czescy czytelnicy znali już z przekładów nazwiska Ryszarda Kapuścińskiego czy Hanny

1 M. Piechota, Pochopit a prevyprávět: o uméní reportáže [w:] M. Benešová, R. Rusin Dybalska, L. Zakopalová i in., Fenomén: Polská literárni reportáž, Praha 2016, s. 109. Jeśli nie zaznaczono inaczej, thumaczenie własne autorki - M.B.].

2 M. Szczygieł, Gottland, tłum. H. Stachová, Praha 2007. 
Krall, to właśnie poczytny tekst Mariusza Szczygła, odkrywający historie często nieznane nawet samym Czechom, zwrócił uwagę na tradycję polskiego reportażu i otworzył drzwi czeskich wydawców kolejnym polskim reporterom.

Właśnie czeski odbiór Gottlandu zwrócił uwagę nie tylko na to, co może przyciągać czeskich czytelników do polskiego reportażu, ale także ujawnił wiele problemów czy nieporozumień, z jakimi spotykamy się w czeskim odbiorze tego gatunku. Biorąc pod uwagę odmienne tradycje gatunku reportażowego w Czechach i w Polsce ${ }^{3}$ oraz fakt, że to Polak pisze o Czechach, nie jest zaskakujące, że wiele recenzji Gottlandu miało na celu przede wszystkim coś w rodzaju lektury weryfikacyjnej, czyli zdemaskowanie domniemanych błędów czy nieścisłości pojawiających się w tekście. Krytyk Josef Chuchma, autor bodaj pierwszej wnikliwej recenzji Gottlandu, wydaje się nieco zaskoczony literackimi walorami tekstu, należącego przecież do gatunku literatury non-fiction. Przypomnijmy, że w Czechach, nawet wśród medioznawców, dosyć powszechne jest przekonanie, iż współczesny reportaż zbliża się raczej do dziennikarstwa śledczego oraz podobnych form niż do literatury i - między innymi pod wpływem mediów wizualnych - pełni (lub powinien pełnić) przede wszystkim funkcję informacyjną i dokumentacyjną, ewentualnie krytyczną bądź kontrolną ${ }^{4}$.

Inne stwierdzenie Josefa Chuchmy, który skądinąd dość konsekwentnie śledzi polski reportaż i często wnosi do debaty na ten temat inspirujące głosy polemiczne, dobrze jednak ilustruje specyficzny sposób czytania polskich tekstów o Czechach czeskimi oczami. Krytyk bowiem pisze:

Jeśli tytułowy motyw książki Szczygła pozostaje kwestią osobistej interpretacji, to niektóre inne fragmenty są faktograficznie nie do utrzymania, przy czym jeden rodzaj nieścisłości dotyczy charakterystyk, a drugi stricte faktów. Autor stwierdza na przykład, że reżim czechosłowacki po wydarzeniach na Węgrzech w 1956 roku „staje się coraz bardziej surowy”. W porównaniu z czym? Z pierwszą połową lat pię́dziesiątych? Bzdura. Terror mimo wszystko słabnie, sytuacja w kulturze nieco się rozluźnia. (...) Albo: „Prasa i telewizja z dnia na dzień przestały być bezbarwne. Z teatrów oraz kin zniknęła nuda" - charakteryzuje Szczygieł Praską Wiosnę. I znowu bzdura: czeski teatr był znakomity już na długo przed 1968 rokiem (epoka Krejčy w Teatrze Narodowym, a potem w teatrze Za Branou, praca Grossmana w teatrze Na Zábradlí, Semafor itp.) A co z czeską falą filmową lat sześćdziesiątych? A czasopismami „Literární noviny” czy „Tvár”? ?5

3 Więcej informacji zob. na przykład: L. Zakopalová, Český kontext: recepce, preklady a domácí tradice [w:] M. Benešová, R. Rusin Dybalska, L. Zakopalová i in., dz. cyt., s. 73-96.

4 Zob. na przykład D. Mocná, Reportáž [w:] Encyklopedie literárnich žánrü, red. D. Mocná, J. Peterka i in., Praha-Litomyšl 2004, s. 568-573.

5 J. Chuchma, Prý je tady bohem Gott, „Mladá fronta DNES - Kavárna”, 27.10.2007, s. D5-D6. Dostępne również na: https://www.idnes.cz/zpravy/archiv/pry-je-tady-bohem-gott. A080111_182446_kavarna_bos, dostęp: 8.06.2021. 
Później czeski krytyk „poprawia” autora, wymienia kilka kolejnych jego rzekomych błędów merytorycznych i prostuje informacje podawane przez Szczygła. Gatunek reportażu powinien być przecież oparty na weryfikowalnych faktach... (Swoją drogą, o tym, co czeski krytyk rozumie przez „fakt” i jak fakt ujmowany jest w teorii reportażu, można byłoby napisać kilka kolejnych artykułów).

Chuchma nie boi się stwierdzić, iż Szczygieł w pewnym stopniu zrezygnował ze ścisłości analitycznej na rzecz barwności, plastyczności i atrakcyjności przekazu. „Jednym ograniczeniem jest reportaż jako taki, czyli jako gatunek rządzący się własnymi regułami; kolejne ograniczenia dodaje sam warszawski autor i jego podejście do tego gatunku"6. Josef Chuchma zwraca w ten sposób uwagę nie tylko na wyróżniki oraz cechy strukturalne gatunku reportażu (hybrydyczność, literackość, połączenie subiektywizmu i obiektywizmu itp.), ale także na osobiste spojrzenie reportera i jego indywidualne podejście do tematu? ${ }^{7}$.

Właśnie stopień subiektywizmu, czyli sposób, w jaki w utworze uwidacznia się stosunek narratora do opisywanej rzeczywistości, sprawia w czeskiej recepcji reportażu największe kłopoty (chodzi na przykład o osobiste obserwacje reportera, ewentualnie komentarze, wypowiedzi bohaterów lub ich stylizacje, sam dobór opisywanych elementów rzeczywistości). W takich momentach czeska debata na temat reportażu skupia się zasadniczo na tym, w jakim stopniu subiektywizm reportera może zaciemniać opis rzeczywistości albo nawet zakłamywać fakty (jak zdaje się sugerować na przykład recenzja Josefa Chuchmy), a w jakim stopniu uwypukla przekaz reporterski.

\section{Nie tylko Szczygieł, czyli gatunkowe wyzwanie dla czeskich czytelników}

Reportaże Szczygła wpisują się w koncepcję tak zwanego reportażu literackiego, między innymi dzięki umiejętności precyzyjnej i przemyślanej kompozycji tekstu, oryginalnemu poczuciu humoru czy ciekawemu wymiarowi intertekstualnemu. Mariusz Szczygieł stał się twarzą polskiego reportażu w Czechach i jednoznacznie rozpoznawalnym nazwiskiem, które przyczynia się do popularyzacji tego gatunku wśród czeskich czytelników.

Nie mniej interesujące jest jednak spojrzenie na to, jak czescy wydawcy nawiązali do sukcesu Gottlandu, a więc między innymi na to, jakie kolejne teksty reportażowe ukazały się w czeskim przekładzie i jak zostały przyjęte. Do

6 Tamże.

7 Więcej na temat czeskiej recepcji tekstów Szczygła zob. na przykład L. Zakopalová, dz. cyt., s. 73-96 lub I. Mroczek, „Gottland” Mariusza Szczygta w czeskim przektadzie i jego czeska recepcja, „Przekłady Literatur Słowiańskich” 2011, nr 2. 
2007 roku, kiedy wydano Gottland, polskie książki reportażowe pojawiały się raczej sporadycznie, bez bardziej przemyślanej koncepcji wydawniczej. Sukces Gottlandu sprawił, że jego czeski wydawca, wydawnictwo Dokořán we współpracy z wydawnictwem Jaroslava Jiskrová - Máj, stworzył całą serię poświęconą fenomenowi polskiego reportażu literackiego. Do tej pory ukazało się w jej ramach piętnaście tytułów.

Dla czeskiej recepcji polskich reportaży dosyć charakterystyczne jest odmienne przyjęcie dwóch pozycji książkowych wydanych po sukcesie Gottlandu ${ }^{8}$, z których jedna reprezentuje temat polski (Bóg zaptać Wojciecha Tochmana ${ }^{9}$ ) a druga bliskowschodni (Izrael już nie frunie Pawła Smoleńskiego ${ }^{10}$ ). Choć niektórzy z recenzentów zwracali uwagę, że wybór książki Tochmana jest trafny i pozwoli czeskim czytelnikom zapoznać się bliżej z tradycją polskiego reportażu, między innymi przez pokazanie wydarzeń i traum, które poruszają polskie społeczeństwo, książka trudniej trafiała do czytelników.

Michael Alexa, polonista i tłumacz kilku polskich tekstów reportażowych, w swojej recenzji pisze: „Tochman wciąga czytelnika w świat polskich traum, które bynajmniej nie są nieciekawe poza granicami, i przedstawia je z chirurgiczną precyzją wyjątkowego stylisty i niezwykle zdolnego dziennikarza" ${ }^{11}$. Docenia też fakt, że Tochman operuje różnymi wariantami gatunkowymi reportażu (biograficznym, śledczym, reportażem w formie fikcyjnego kazania itp.), co jest niewątpliwie istotne w odniesieniu do dopiero rodzącej się wówczas czeskiej recepcji polskiego reportażu. Większość innych recenzentów skupiała się jednak raczej na porównaniu stylów Tochmana i Szczygła, którego teksty przez jakiś czas służyły za dogodny materiał porównawczy. Inny recenzent, Tomáš Weiss, trafnie zauważa, że Tochman jest przedstawicielem innego typu reportażu niż Szczygieł: „zamiast „swojskiego” tonu Szczygła mamy przed sobą zbiór wstrząsających thrillerów społecznych i egzystencjalnych" ${ }^{\prime 2}$. Być może również z tego powodu - oprócz polskiej tematyki, która w Czechach nie jest tak atrakcyjna jak czeska tematyka w Polsce - książka Bóg zaptać nie cieszyła się takim zainteresowaniem czeskich czytelników.

8 Pomijam w tym momencie książkę Krzysztofa Vargi Gulasz z turula (tenże, Guláš z turula, tłum. P. Peč, Praha 2010), między innymi dlatego, że jej klasyfikacja gatunkowa jest bardziej problematyczna. W większości czeskich recenzji tej publikacji częściej pojawia się termin „esej”.

9 W. Tochman, Pánbi̊h zaplat', tłum. B. Gregorová, Praha 2013.

10 P. Smoleński, Izrael už se nevznáš̌i, tłum. L. Zakopalová, M. Benešová, Praha 2013. Książka ta, w przeciwieństwie do reportaży Tochmana, została wznowiona w 2016 roku, co świadczy o różnej sprzedaży obu tytułów.

11 M. Alexa, Tochman, Wojciech. „Pánbuih zaplat”, ,iLiteratura”, 17.12.2013, http://www.iliteratura.cz/Clanek/32511/tochman-wojciech-panbuh-zaplat, dostęp: 8.06.2021.

12 T. Weiss, Mastná a slaná fakta, „Respekt”, 4.01 .2014 (dostępne również na: https://www. dokoran.cz/recenze/1389104796.pdf, dostęp: 8.06.2021). Opiniom ekspertów w tym wypadku wtórują niektóre reakcje czytelników, na przykład: „czytałam, nie wiedząc, co to za książka. Pomyślałam, że to dość surowe opowiadania... potem uświadomiłam sobie, że to nie są opowiadania" (zob. https://www.databazeknih.cz/knihy/panbuh-zaplat-184284, dostęp: 8.06.2021). 
Następnie Weiss pyta wprost: „Po Niemcach, Szwedach, Francuzach, ale także na przykład Austriakach, Czesi mogliby wreszcie zacząć zadawać sobie pytania: Dlaczego Polacy mają coś, czego my nie mamy? Myślę tu o żywej tradycji reportażu literackiego"13. Zresztą dopiero dzięki polskim reporterom termin ten zaczął funkcjonować również w czeskim środowisku. Josef Chuchma proponuje dla reportaży Tochmana termin „literatura dokumentalna” (jako swoistą analogię do pojęcia film dokumentalny). Choć takie próby definiowania gatunku nie są zwykle poparte mocniejszym zapleczem teoretycznym, w środowisku czeskim są cenne, gdyż świadczą o świadomości krytyków, że reportaż literacki ma swoje specyficzne wyznaczniki gatunkowe i nie jest definiowany wyłącznie przez pryzmat ciekawego czy egzotycznego tematu.

Co więcej, polskie, a później także inne obcojęzyczne reportaże wypełniły swoistą białą plamę na rynku. Jak już wspomniano, zwłaszcza tradycja reportażu książkowego jest w Czechach słaba. Choć w latach dziewięćdziesiątych nastąpiło pewne ożywienie gatunku reportażu prasowego dzięki tekstom publikowanym na łamach tygodników „Reflex” czy „Týden” albo w dzienniku „Lidové noviny”, okazało się, że zakłócenia w rozwoju i ciągłości czeskiego reportażu po drugiej wojnie światowej były poważniejsze, niż sądzono. Na pewno znacznie poważniejsze niż w wypadku polskiego reportażu. Czegoś takiego jak „czeska szkoła reportażu” w zasadzie nie ma. Innym ważnym czynnikiem była bez wątpienia również transformacja środowiska medialnego na przełomie tysiącleci, która jeszcze bardziej skomplikowała pozycję tego gatunku (zwłaszcza w jego formie prasowej). Polscy reporterzy przenieśli się w tym czasie z redakcji gazet do wydawnictw książkowych, czescy autorzy nie mieli skąd się przenieść. Wszystko to ma oczywiście znaczący wpływ na odbiór tekstów reportażowych, do których czeski czytelnik po prostu nie jest przyzwyczajony.

Przytoczmy jeszcze konkluzję recenzji Weissa, ponieważ jest ona pod wieloma względami symptomatyczna dla ówczesnego spojrzenia czeskich krytyków literackich na tradycję polskiego reportażu:

Pozwolić sobie na napisanie reportażu subiektywnie, mimo że pozostają w nim fakty - to siła polskiej tradycji dziennikarskiej, którą do dziś pielęgnuje np. dziennik „Gazeta Wyborcza”. (...) Kulturalni Polacy od lat przyzwyczaili się do tej formy i za jej pośrednictwem chętnie czytają także o wydarzeniach i ludziach w Rwandzie czy na Filipinach. W Warszawie działa nawet Instytut Reportażu, gdzie młodzi dziennikarze uczą się, jak pisać o świecie w sposób poprawny faktograficznie, a jednocześnie sugestywny. Jak potrafią to Mariusz Szczygieł, Paweł Smoleński czy Wojciech Tochman ${ }^{14}$.

\footnotetext{
13 Tamże.

14 Tamże.
} 


\section{Podwójna rola reportera}

Temat, który podejmuje Paweł Smoleński w drugiej z wyżej wymienionych książek, Izrael już nie frunie, czyli - bardzo ogólnie rzecz ujmując - kwestia współżycia izraelsko-palestyńskiego, niewątpliwie ma potencjał, aby odbić się echem nie tylko wśród czeskich czytelników. Ciekawe jest jednak to, że czeskie wydanie jego książki wywołało dyskusję zarówno nad samym tematem (na przykład w odniesieniu do obrazu medialnego i dominujących w nim narracji), jak i nad wyznacznikami gatunku tak zwanego reportażu literackiego, czy też nad pozycją i statusem reportera i/lub narratora. Spośród różnych ról, jakie reporter może przyjmować, czeskich czytelników najbardziej ciekawi obserwacja uczestnicząca. Reporter wchodzi w określone środowisko i od wewnątrz nie tylko obserwuje opisywane sytuacje i towarzyszy swoim bohaterom, ale także w opisywanych sytuacjach - przynajmniej w pewnym stopniu - uczestniczy. Jiří Trávníček, historyk i krytyk literatury, tak wyraża dylemat związany z podwójną rolą reportera:

Polski autor bardzo chętnie daje się wplątać w mikrohistorie różnych ludzi, rozmawia z nimi, wysłuchuje. A jednak - o dziwo - te rozmowy nie są osobiste, nie ma w nich uczuć ani prywatnych historyjek, ale są to rozmowy polityczne. Prywatne bardzo szybko przeistacza się w polityczne, a polityczne nieraz w metafizyczne ${ }^{15}$.

Autor recenzji podkreśla stałe napięcie nie tylko między „prywatnym” a „politycznym", ale także między poznawaniem (intelektualną refleksją) i osobistym, wewnętrznym doświadczaniem (przeżywaniem).Jego słowa mogą być ciekawym „niepolskim” komentarzem do tradycyjnych sporów o stopień subiektywizmu w reportażu literackim: „Równie dobrze udaje mu się [Smoleńskiemu - M.B.] być ponad sprawą, jak i wewnątrz niej. Jest ponad sprawą w sensie umiejętności szerokiego spojrzenia, a wewnątrz niej głównie w tym sensie, że »obmacuje« wszystko po swojemu"16.

Postawa reportera, wspomniana w przypadku Smoleńskiego, oczywiście wpływa też na „jego” obraz rzeczywistości. Wielu czeskich krytyków doceniało wielowymiarowość reportaży z tomu Izrael już nie frunie, fakt, że reporter oddaje głos różnym warstwom izraelskiego społeczeństwa. Każdy z bohaterów reportaży Pawła Smoleńskiego doświadcza na własnej skórze zarówno pozytywnych, jak i negatywnych skutków tej różnorodności i zostaje - mówiąc obrazowo - wrzucony w nieustanne zderzanie się

15 J. Trávníček, Kam dál, Izraeli...?, „Host” 2014, nr 5, s. 86 (dostępne również na: https:// www.dokoran.cz/recenze/1401884161.pdf, dostęp: 8.06.2021).

16 Tamże, s. 87. 
sprzecznych narratywów, co wielu czeskich recenzentów i czytelników potrafiło docenicíc ${ }^{17}$.

Jiří Trávníček podsumowuje:

Smoleński pokazuje, że o wiele bardziej produktywny model dzisiejszego pisania, w tym pisania literackiego, polega na kontakcie z rzeczywistością, z konkretem, z ulotnym empirycznym szczegółem. Na umiejętności nadania tej rzeczywistości jak najbardziej wiarygodnego przełożenia na tekst. Tak, żeby mówiła sama za siebie, a jednocześnie przedstawiała coś więcej. Jako sprawozdanie i jednocześnie szyfr, jako gulgocząca polifonia, a zarazem prorocza wizja ${ }^{18}$.

Pewne trudności w zdefiniowaniu gatunku, którym posługują się Smoleński i inni polscy reportażyści, można wyczuć w tekście Marka Motkki, który w reportażach z tomu Izrael już nie frunie znajduje ślady eseju, choć nie precyzuje, co skłania go do takiej opinii. Rozmówców Smoleńskiego nazywa „współnarratorami” (stosując termin znany przede wszystkim z teorii literatury, co również nie jest przypadkiem), zwraca także uwagę na „efektowne prowadzenie narracji”, nie podaje jednak, jakie konkretne cechy ją wzbogacają ${ }^{19}$. Niech to będzie dowodem, jak nieuchwytne dla niektórych czeskich czytelników pozostaje zjawisko reportażu literackiego.

Niewiele osób stara się jednak uwzględniać w odbiorze polskich tekstów reportażowych czeską myśl teoretyczną o gatunku reportażu (choć i na nią z pewnością mają wpływ odmienne tradycje reportażowe w Czechach i w Polsce). Przydatne mogą być na przykład rozważania czeskiej teoretyczki mediów Barbory Osvaldovej, która stwierdza, że reportaż

jest połączeniem zrozumienia i doświadczenia, ich przecięciem w czasie. Pod tym względem relacjonowanie i reportaż to dwie powiązane ze sobą czynności. Informowanie jest wspólną cechą obu (...), podobnie jak dążenie do bycia tam, gdzie coś się dzieje, przekazywania tego, co się widzi i słyszy. Jednak dla reportażu ważne jest też przekazanie tego, co zostało przeżyte ${ }^{20}$.

Nacisk położony na kategorię doświadczenia jest tutaj ważny. Doświadczenie i osobiste przeżycie reportera staje się fundamentem struktury narracyjnej reportażu, ale coraz częściej także jednym z podstawowych wyznaczników tego gatunku.

17 Por. też reakcje czytelników: https://www.databazeknih.cz/knihy/izrael-uz-se-nevznasi-181859, dostęp: 8.06.2021.

18 J. Trávníček, dz. cyt., s. 87.

19 M. Motka, Smoleński, Pawet. Izrael už se nevznáší, ,iLiteratura”, 2.01.2014, http://www. iliteratura.cz/Clanek/32559/smolenski-pawe-izrael-uz-se-nevznasi, dostęp: 8.06.2021.

20 B. Osvaldová, Reportáż a reportéri [w:] O reportáżi, o reportérech, red. B. Osvaldová, R. Kopáč, A. Tejkalová, Praha 2010, s. 6. 


\section{Czeski obraz polskiego reportażu}

Oprócz wspomnianych już książek Wojciecha Tochmana, Pawła Smoleńskiego i Mariusza Szczygła nakładem wydawnictwa Dokořán / Jaroslava Jiskrová Máj ukazało się jeszcze dwanaście innych polskich tytułów reportażowych, choć w wypadku niektórych jednoznaczna klasyfikacja gatunkowa jest nieco problematyczna: Gulasz z turula Krzysztofa Vargi (2010), Zrób sobie raj (2011) i Láska nebeská (2012) Mariusza Szczygła (2012), Café Museum Roberta Makłowicza (2014), Irak. Piekto w raju Pawła Smoleńskiego (2015), Bukareszt. Kurz i krew Małgorzaty Rejmer (2015), Cygan to cygan Lydii Ostałowskiej (2016), Zabójca $z$ miasta moreli. Reportaze $z$ Turcji Witolda Szabłowskiego (2016) ${ }^{21}$, Projekt: prawda Mariusza Szczygła (2016), Toastza przodków Wojciecha Góreckiego (2017) oraz Nie ma Mariusza Szczygła (2019). Najnowszym projektem jest książka Witolda Szabłowskiego Jak nakarmić dyktatora (czerwiec 2021). Widać między innymi, że wydawcy z Dokořán stawiają raczej na sprawdzone nazwiska.

Przeciwieństwem jest słowackie wydawnictwo Absynt, które powstało w 2015 roku jako projekt dwóch entuzjastów i miłośników polskiego reportażu, Juraja Koudeli i Filipa Ostrowskiego, i pierwotnie specjalizowało się właśnie w tej tematyce. Później rozszerzyło swój zakres o książki reportażowe także z innych obszarów językowych ${ }^{22}$, jednak polskie teksty nadal odgrywają znaczącą rolę w ich planach wydawniczych. Widać to również w tekstach, które Absynt opublikował w ostatnich latach w tłumaczeniu na język czeski w ramach serii „Reporterzy wyklęci": Ganbare! Warsztaty umierania Katarzyny Boni (2017), Miedzianka. Historia znikania Filipa Springera (2017), Jakbyśkamień jadta Wojciecha Tochmana (2017), Ku Klux Klan. Tu mieszka mitość Katarzyny Surmiak-Domańskiej (2017), Król kier znów na wylocie Hanny Krall (2018), Modlitwa o deszcz Wojciecha Jagielskiego (2018) i Wszystkie dzieci Louisa Kamila Bałuka (2019). Specyficznym dodatkiem są nowe, zredagowane wydania książek Ryszarda Kapuścińskiego, przetłumaczone już w latach osiemdziesiątych ubiegłego wieku przez dziennikarza Dušana Provazníka. W ten sposób Absynt opublikował Szachinszacha (2017), Imperium (2018) oraz Wojne futbolowa (2021) ${ }^{23}$.

21 W wypadku tego tytułu ciekawy jest fakt, że w czeskim wydaniu termin „reportaż” z podtytułu książki został zastąpiony słowem „opowieści” (Vrah z mèsta merunèk. Př̀ibèhy z Turecka).

22 Co ciekawe, na Słowacji, w tłumaczeniach na język słowacki, wydawnictwo Absynt stawia również na autorów niepolskich, których nazwiska znane są na całym świecie i którzy w ten sposób pomagają mocniej zakotwiczyć gatunek reportażu w środowisku słowackich czytelników. Są wśród nich Swietłana Aleksijewicz czy Martin Pollack.

23 Dodajmy, że pojedyncze tłumaczenia ukazują się czasem także poza dwoma wymienionymi wydawnictwami. W tych wypadkach nie chodzi jednak o celową i przemyślaną strategię. Tak ukazały się na przykład Farby wodne Lidii Ostałowskiej wydane przez P3K (L. Ostałowska, Akvarely pro Mengeleho, tłum. L. Zakopalová, Praha 2014) albo antologia 20 lat nowej Polski w reportażach wedtug Mariusza Szczygta w słowackim wydawnictwie Premedia (20 let nového Polska v reportážčch podle Mariusze Szczygieta, red. M. Szczygieł, thum. M. Benešová, B. Gregorová, H. Stachová, L. Zakopalová, Bratislava 2014). 
Wydawnictwo Absynt częściej prezentuje nowe nazwiska (nowe nie tylko w czeskim, ale często także w polskim środowisku), stara się na bieżąco śledzić polską produkcję i wybierać takie tematy, które mają potencjał, by zainteresować również czeskich czytelników, albo odbijają się szerokim echem w mediach czy debacie społecznej ${ }^{24}$. Dziś już niemal klasyczne teksty, na przykład książka Tochmana o traumie konfliktu na Bałkanach, uzupełniane są przez inspirujące prace młodych reporterów.

Droga czytelniczko, drogi czytelniku, mogłoby się wydawać, że ta książka rozwiązuje tylko dziwną tajemnicę holenderskiej kliniki reprodukcyjnej, w której jeden mężczyzna spłodził ponad dwieście dzieci. Reportaż Kamila Bałuka jest jednak przede wszystkim o rodzinie. Co to znaczy być ojcem? A co być dzieckiem? Jak to jest, gdy dopiero w dojrzałym wieku dowiadujesz się, że masz liczne rodzeństwo, o którym wcześniej nie wiedziałeś? W rękach trzymasz piękną opowieść o najbardziej kruchych rzeczach na świecie - relacjach międzyludzkich ${ }^{25}$.

Tymi słowami wydawcy przedstawiają czeskiemu czytelnikowi $W_{\text {szystkie }} d z i e c i$ Louisa Kamila Bałuka. Zdają sobie sprawę z wielowarstwowości historii, która pozornie nie ma wiele do zaoferowania poza jednorazową sensacją medialną. Potrafią jednak także komunikować się ze swoimi (potencjalnymi) czytelnikami ${ }^{26}$. Reportaż Bałuka jest dobrym przykładem tekstu, który spotkał się z zainteresowaniem czeskich i słowackich czytelników. Świadczą o tym między innymi reakcje na portalach społecznościowych lub na kilku zorganizowanych w Czechach spotkaniach autorskich oraz opinie krytyków literackich dotyczące nie tylko sposobu ujęcia tematu, ale także formy. Na przykład Aňa Ostrihoňová pisze: „Gdyby debiut polskiego dziennikarza Kamila Bałuka byl filmem, otrzymałby Oscara za montaż. Jego książkę reportażową czyta się jak kryminal"27.

Synkretyzm gatunkowy, oryginalne strategie narracyjne i eksperymenty formalne cechują też Ganbare! Warsztaty umierania Katarzyny Boni. Temat trzęsienia ziemi w Japonii w 2011 roku i następującej po nim awarii w Fukushimie pojawiał się regularnie także w czeskich mediach. Być może również dlatego niektórzy

${ }^{24}$ W tej chwili dotyczy to na przykład przygotowywanej książki Joanny Gierak-Onoszko 27 śmierci Toby'ego Obeda.

${ }^{25}$ K. Bałuk, Vsechny Louisovy dèti, tłum. M. Benešová, Praha 2019, tekst na okładce książki [tłum. - M.B.].

26 Książki z serii „Reporterzy wyklęci” mają jednolitą szatę graficzną (nawiązującą do oryginalnej serii słowackiej). Czarno-białej okładce z fotografią ilustrującą temat książki i krótkim cytatem z tekstu towarzyszy odpinany kolorowy pasek, który można wykorzystać jako zakładkę do książki, oraz grzbiet w tym samym kolorze. Seria funkcjonuje więc w świadomości czytelników jako pewien znak firmowy, przez wielu już dość wyraźnie rozpoznawalny (co autorka niniejszego tekstu zweryfikowała w praktyce). Wydawnictwo jest także bardzo aktywne w mediach społecznościowych.

27 A. Ostrihoňová, Kamil Baluk:Vsetky Louisove deti, Rádio_FM, 28.05.2019, https://fm.rtvs. sk/relacie/knizny-tip-ane-ostrihonovej/196784/kamil-baluk-vsetky-louisove-deti, dostęp: 8.06.2021. 
czescy recenzenci i czytelnicy potrafili zwrócić uwagę na specyficzną strategię narracyjną zastosowaną przez autorkę czy na przemyślaną kompozycję książki:

Siła jej reportażu tkwi jednak nie w oryginalności zebranego materiału, ale w umiejętności połączenia czasem smutnych, a czasem heroicznych losów ludzi z szerszym kontekstem japońskiej historii i szczegółami japońskiej kultury. I, oczywiście, opowiedzenia tego wszystkiego w fascynujący sposób. Potwierdzeniem mistrzostwa autorki jest swoisty aneks - tekst Warsztaty umierania o kursie w Tokio, gdzie ludzie uczą się, jak to jest umierać powoli na raka. Imponujący tekst wykorzystujący drugą osobę (bohaterem jest więc sam czytelnik) przyprawia o dreszcze ${ }^{28}$.

Inni mają świadomość, że Boni wykracza poza granice „konwencjonalnego reportażu”: „Autorka porzuca ton konwencjonalnego reportażu opisując na przykład, jak Godzilla jako potwór została w świadomości Japończyków zastąpiona - lub uzupełniona, jak kto woli - przez bestialskie »postacie « związane z katastrofą w Fukushimie" ${ }^{29}$. Recenzent Kryštof Eder podkreśla również, że reporterka celowo odchodzi od „obiektywnej i nieobciążonej perspektywą er-formy” i nie boi się używać „atrakcyjnej (i, trzeba dodać, bardzo adekwatnie użytej) du-formy" ${ }^{\prime 30}$. Jeszcze inni wiążą eksperymenty formalne Boni z książkową, a nie prasową odmianą reportażu: „Autorka w przemyślany sposób łączy różne warianty gatunkowe reportażu literackiego i nie boi się eksperymentów formalnych, których reportaż na mniejszej powierzchni nie byłby w stanie udźwignąc ${ }^{\prime 31}$. Zresztą również książkowa forma reportażu jest w czeskim środowisku nietypowa i czescy czytelnicy dopiero stopniowo się z nią oswajają.

Jak starałam się choć pobieżnie wskazać, wyraźnym wyjątkiem w czeskiej recepcji polskiego reportażu był i nadal jest Mariusz Szczygieł, którego pisarstwo, z Gottlandem na czele, wzbudziło wśród Czechów zainteresowanie nieporównywalne $\mathrm{z}$ innymi polskimi tekstami reportażowymi opublikowanymi po 1989 roku. Należy jednak dodać, że wynika to głównie z poruszanej tematyki. Dopiero wtórnie, a zwłaszcza w związku z kolejnymi tłumaczonymi książkami polskich autorów, zaczęto zwracać większą uwagę także na status gatunkowy tych tekstów, między innymi w porównaniu z diametralnie odmienną sytuacją czeską - brak gatunku reportażu książkowego w środowisku czeskim w dużym

28 K. Veselý,Jak žit se smrtí. Nad reportážemi Katarzyny Boni z Japonska po tsunami, „Právo Salon”, 7.12.2017 (dostępne również na: https://www.novinky.cz/kultura/salon/clanek/jak-zit-se-smrti-nad-reportazemi-katarzyny-boni-z-japonska-po-tsunami-40053415, dostęp: 8.06.2021).

29 K. Eder, Nejvètši tragédie 21. století? Jak souvisí havárie elektrárny Fukušima s Godzillou?, „Čtidoma.cz”, 28.04.2018, https://www.ctidoma.cz/kultura/2018-04-28-nejvetsi-tragedie-21-stoleti-jak-souvisi-havarie-elektrarny-fukusima-s-godzillou, dostęp: 8.06.2021.

30 Tamże.

31 A. Plasová, Japonsko po roce nula, „Demokratický střed” 2018, nr 2, s. 23 (dostępne również na: https://www.demokratickystred.cz/japonsko-po-roce-nula/, dostęp: 8.06.2021). I co także ważne: „Mimo niewątpliwej egzotyki tych realiów, jej celem nie jest inność, lecz uniwersalność” (tamże). 
stopniu determinuje również sposób czytania reportaży obcojęzycznych. Pomijając Szczygła, czy można jednak stwierdzić, że czeskie przekłady stwarzają przynajmniej w jakimś stopniu reprezentatywny obraz polskiego reportażu? Aby tak się stało, musielibyśmy więcej miejsca poświęcić reportażom o tematyce polskiej (których wydawcy ostatnio unikają, być może obawiając się mniejszego zainteresowania czytelników), a także polskim reportażom śledczym czy granicznemu gatunkowi, jakim jest reportaż biograficzny. Rosnąca liczba tłumaczeń jest zdecydowanie pozytywnym sygnałem. Miejmy nadzieję, że z czasem pojawią się kolejne nazwiska i inne ciekawe teksty. Zainteresowanie czeskich czytelników na pewno udało się rozbudzić.

\section{Bibliografia}

Alexa M., Tochman, Wojciech. Pánbuih zaplat', ,iLiteratura”, 17.12.2013, http://www.iliteratura.cz/Clanek/32511/tochman-wojciech-panbuh-zaplat, dostęp: 8.06.2021.

Bałuk K., Vsechny Louisovy déti, tłum. M. Benešová, Praha 2019.

Chuchma J., Prý je tady bohem Gott, „Mladá fronta DNES - Kavárna”, 27.10.2007.

Eder K., Nejvètši tragédie 21. století? Jak souvisí havárie elektrárny Fukušima s Godzillou?, „Čtidoma.cz”, 28.04.2018, https://www.ctidoma.cz/kultura/2018-04-28-nejvetsi-tragedie-21-stoleti-jak-souvisi-havarie-elektrarny-fukusima-s-godzillou, dostęp: 8.06.2021.

Mocná D., Reportáz [w:] Encyklopedie literárnich žánrů, red. D. Mocná, J. Peterka i in., Praha-Litomyšl 2004.

Motka M., Smoleński, Pawet. Izrael už se nevznáši, „iLiteratura”, 2.01.2014, http:// www.iliteratura.cz/Clanek/32559/smolenski-pawe-izrael-uz-se-nevznasi, dostęp: 8.06.2021.

Mroczek I., „Gottland” Mariusza Szczygta w czeskim przektadzie i jego czeska recepcja, „Przekłady Literatur Słowiańskich” 2011, nr 2.

Ostałowska L., Akvarely pro Mengeleho, tłum. L. Zakopalová, Praha 2014.

Ostrihoňová A., Kamil Baluk: Vsetty Louisove deti, Rádio_FM, 28.05.2019, https:// fm.rtvs.sk/relacie/knizny-tip-ane-ostrihonovej/196784/kamil-baluk-vsetky-louisove-deti, dostęp: 8.06.2021.

Osvaldová B., Reportáz a reportéri [w:] O reportáži, o reportérech, red. B. Osvaldová, R. Kopáč, A. Tejkalová, Praha 2010.

Piechota M., Pochopit a prevevprávět: o umèni reportáže [w:] M. Benešová, R. Rusin Dybalska, L. Zakopalová i in., Fenomén: Polská literárni reportáž, Praha 2016.

Plasová A., Japonsko po roce nula, „Demokratický střed” 2018, nr 2.

Smoleński P., Izrael už se nevznáš́, ttum. L. Zakopalová, M. Benešová, Praha 2013.

Szczygieł M., Gottland, tłum. H. Stachová, Praha 2007.

Tochman W., Pánbi̊h zaplat', ttum. B. Gregorová, Praha 2013.

Trávníček J., Kam dál, Izraeli...?, „Host” 2014, nr 5.

Varga K., Guláš z turula, tłum. P. Peč, Praha 2010. 
Veselý K., Jak žit se smrtí. Nad reportážemi Katarzyny Boni z Japonska po tsunami, „Právo - Salon”, 7.12.2017.

Weiss T., Mastná a slaná fakta, „Respekt”, 4.01.2014.

Zakopalová L., Český kontext: recepce, prekelady a domáci tradice [w:] M. Benešová, R. Rusin Dybalska, L. Zakopalová i in., Fenomén: Polská literárni reportáz, Praha 2016. 